\title{
Functional Screening of Plant Genes Suppressed Salt Sensitive Phenotype of Calcineurin Deficient Mutant through Yeast Complementation Analysis
}

\author{
Seok-Jun Moon², Soo-Kwon Park', Un-Ha Hwang', Jong-Hee Lee', Sang-Ik Han', Min-Hee Nam', \\ Dong-Soo Park' and Dongjin Shin'* \\ ${ }^{1}$ Function Crop Resource Development Division, Department of Functional Crops, National Institute of Crop Science, RDA, Miryang 627-803, \\ Korea \\ ${ }^{2}$ Bio-crop Development Division, National Academy of Agricultural Science, RDA, Suwon 441-857, Korea
}

Received August 17, 2012 /Revised October 19, 2012 /Accepted January 4, 2013

\begin{abstract}
Understanding salt tolerance mechanisms is important for the increase of crop yields, and so, several screening approaches were developed to identify plant genes which are involved in salt tolerance of plants. Here, we transformed the Arabidopsis cDNA library into a salt-sensitive calcineurin $(\mathrm{CaN})$-deficient $(c n b \Delta)$ yeast mutant and isolated the colonies which can suppress salt-sensitive phenotype of cnbs mutant. Through this functional complementation screen, a total of 34 colonies functionally suppressed the salt-sensitive phenotype of cnbs yeast cells, and sequencing analysis revealed that these are 9 genes, including CaS, AtSUMO1 and AtHB-12. Among these genes, the ectopic expression of $C a S$ gene increased salt tolerance in yeast, and $C a S$ transcript was up-regulated under high salinity conditions. CaS-antisense transgenic plants showed reduced root elongation under $100 \mathrm{mM} \mathrm{NaCl}$ treatment compared to the wild type plant, which survived under $150 \mathrm{mM} \mathrm{NaCl}$ treatment, whereas CaS-antisense transgenic plant leaves turned yellow under $150 \mathrm{mM} \mathrm{NaCl}$ treatment. These results indicate that the expression of CaS gene is important for stress tolerance in yeast and plants.
\end{abstract}

Key words : $\mathrm{NaCl}$, salt tolerance, yeast genetic system

\section{Introduction}

Plants frequently encounter various environmental stress conditions such as high salinity and drought. These stresses, especially high salinity, change from altered gene expression and cellular metabolism to plant growth, development, and productivity $[15,19]$. Many researchers have been trying to identify plant genes which are involved in stress tolerance mechanisms through forward genetic approaches.

Late embryogenesis-abundant (LEA) genes are induced by salt stress and abscisic acid (ABA), and function in homeostasis as molecular shields under stress conditions [12, 18]. These $L E A$ genes were initially screened from barley and tomato cDNA libraries through colony hybridization $[3,8]$. Responsive to desiccation (RD) genes of Arabidopsis, including $R D 29 A$, identified through the colony hybridization ap-

\footnotetext{
*Corresponding author

Tel : +82-55-355-1185, Fax : +82-55-352-3059

E-mail : djshin99@korea.kr

This is an Open-Access article distributed under the terms of the Creative Commons Attribution Non-Commercial License (http://creativecommons.org/licenses/by-nc/3.0) which permits unrestricted non-commercial use, distribution, and reproduction in any medium, provided the original work is properly cited.
}

proach, are induced by ABA and desiccation treatments [30]. Especially, RD29A promoter involves dehydration responsive element (DRE), which is important for the rapid response of $R D 29 A$ after dehydration or high salinity treatment $[30,31]$. Two proteins, DREB1A and DREB2A, were identified as transcription factors to bind the DRE sequence of the $R D 29 A$ promoter by using the yeast one-hybrid screening technique [11]. DREB1A transcript is induced under low-temperature conditions and the expression of $D R E B 2 A$ is positively regulated by dehydration. Transgenic Arabidopsis over-expressing each genes show tolerance to freezing and dehydration stress conditions [11].

During the last 10 years, global genome expression profiles in plants have been monitored through microarray technology. In Arabidopsis, expression of more than 7000 genes was monitored using a full-length cDNA microarray and 277, 53, and 194 genes were identified as drought-, cold-, and high salinity-inducible genes, respectively [22]. An oligomer microarray, covering about 37,000 genes of rice, was used to monitor genome expression profiling, and revealed organ specific gene regulation under drought or high salinity conditions [33]. Promoters of down-regulated genes were analyzed and novel promoter motifs associated with 
gene repressed by drought were suggested in rice shoot and panicle [33].

The numerous cellular mechanisms of salt tolerance in yeast are conserved in plant cells, and yeast has been used for screening of salt tolerance genes in plants [15, 23]. Arabidopsis salt tolerance protein (STO) and salt tolerance zinc finger (STZ) were identified as proteins complementing the salt-sensitive phenotype of yeast calcineurin mutants [10]. Expression of STZ was rapidly increased under abiotic stress conditions such as high salinity and drought. STZ protein has a bind ability to cause $\mathrm{A}(\mathrm{G} / \mathrm{C}) \mathrm{T}$ repeats within an EP2 sequence, and functions as a transcription repressor to increase stress tolerance following growth retardation [21]. Even if the mRNA level of the STO gene was not increased, STO protein interacted with Myb transcription factor homologue, and overexpression of STO showed tolerance to salt stress conditions [16]. Plasma membrane $\mathrm{Na}^{+} / \mathrm{H}^{+}$antiporter, salt tolerance locus SOS1 complements salt tolerance of the nha1hhx1 double yeast mutant, which is deficient in endogenous $\mathrm{Na}^{+}$transporters, and controls long-distance $\mathrm{Na}^{+}$transport in plants [24]. Arabidopsis vacuolar $\mathrm{Na}^{+} / \mathrm{H}^{+}$antiporters, AtNHK1, 2, and 5, suppressed the salt- and hygromycin-sensitive phenotype of a yeast nhx1 mutant [32]. In this study, we screened plant salt-stress related genes using a unicellular yeast genetic system. Among salt-stress related genes, we chose CaS gene, and examined the biological role of $C a S$ in high salinity stress responses in plants.

\section{Materials and Methods}

\section{Plant material and yeast strain}

Arabidopsis thaliana (ecotype Columbia) was grown in a growth chamber at $22^{\circ} \mathrm{C}$ under conditions of $70 \%$ relative humidity and a $16 \mathrm{~h}$ light/8 h dark cycle. Saccharomyces cerevisiae YP9 stain (Mata ura3 leu2 his3 trp1 ade2 lys2 cnb1::HIS3, isogenic to YPH499) was mutated in calcineurin B subunit and was used for screening salt stress-related genes [14].

Screening of cDNA clones complementing a $\mathrm{NaCl}$ stress-sensitive strain of yeast YP9

An Arabidopsis expression library constructed pGAD424 vector (Clontech, CA, USA) was introduced into the mutant yeast by the LiOAc method [25]. Approximately $2.5 \times 10^{5}$ transformants were selected for leucine prototrophy by plating on synthetic complete medium lacking leucine (SC-Leu), and were pooled to yield a transformed yeast library. The transformed yeast cells were then plated at a density of $10^{7}$ cells per YPD ( $1 \%$ yeast extract $/ 2 \%$ peptone/ $2 \%$ dextrose) plate supplemented with $1.1 \mathrm{M} \mathrm{NaCl}$. Putative positive colonies were obtained 4 days after plating. Plasmid DNAs were isolated from the yeast cells [25] and were reintroduced into YP9 yeast cells to confirm complementation. cDNAs constructed pGAD424 vector were sequenced with the dideoxy termination method using a dye-terminator cycle sequencing kit [25]. The sequencing reaction was analyzed using an automatic sequencer (ABI, MD, USA).

\section{Spot assay}

The full-length of CaS gene was subcloned into pYES2, an expression vector with the URA3 selection marker and the galactose-inducible GAL1 promoter [25]. The construct was introduced into the YP9 strain by LiOAc method, and the transformed cells were plated on a SC-Ura plate. The transformed cells were grown in SC-Ura medium overnight. Aliquots $(2 \mu \mathrm{l})$ from an exponentially growing culture of cells at an O.D.600 of 0.1 were serially diluted (1:10, 1:100, 1:1,000) and were spotted onto YPGal (1\% yeast extract/2\% peptone $/ 2 \%$ galactose) plates containing $\mathrm{NaCl}(1.1 \mathrm{M})$. The photograph was taken after 3 day at $30^{\circ} \mathrm{C}$.

\section{Semi-quantitative RT-PCR analysis}

2-week-old Arabidopsis seedlings were treated with $\mathrm{NaCl}$ $(100 \mathrm{mM})$ for various durations $(0,0.5,1$ and $6 \mathrm{hr})$ [25], and total RNA from the Arabidopsis seedlings was isolated with RNeasy Plant Mini kit, according to manufacturer's instruction (Qiagen, USA). Semi-quantitative RT-PCR was performed with specific primers. CaS; 5'-GGACTCGTACACGG ATTCGG-3' and 5'-GTTCCGGACCTAGTGCCAAA-3'. KIN1; 5'-AGCGGGAGGTGTTAACTTCG-3' and 5'-TGGGGAGTTT GATCTTTC GCA-3'. Actin; 5'-TCGCTGACCGTATGAGC AAA-3' and 5'-TGGAGATCCACATCTGTA ACCA-3'.

\section{Root growth measurement}

To compare root elongation, seeds of wild-type and transgenic plants were washed with $2 \% \mathrm{NaOCl}$ solution and were plated on 1/2 MS medium. Plates containing seeds were stratified at $4^{\circ} \mathrm{C}$ for 4 days and were then transferred to a growth chamber $\left(22^{\circ} \mathrm{C}\right.$ under a 16-h-light/8-h-dark regime) in a vertical orientation [29]. Seedlings grown for 7 days were transferred to $1 / 2 \mathrm{MS}$ medium with or without $\mathrm{NaCl}$. Seedlings were further incubated in the growth chamber for another 5 days and root elongation was then measured. 
Three replicate plates were used for each treatment to ensure the reproducibility of the data.

\section{Results}

Screening of plant genes showing increased salt tolerance in yeast

Under abiotic stress conditions, such as high salinity, plants accumulate the phytohormone $\mathrm{ABA}$, which controls regulatory signal networks for survival. It has been also suggested that salt tolerance mechanisms are similar between plants and yeast. To identify plant genes that confer salt tolerance in plant and yeast, Arabidopsis cDNA library was introduced to CaN null mutant (cnb」) yeast cells showing salt-sensitive phenotype. Approximately, $2.5 \times 10^{5}$ independent transformants were screened on YPD medium supplemented with $1.1 \mathrm{M} \mathrm{NaCl}$, and more than 100 colonies showing remarkable $\mathrm{NaCl}$ tolerance were obtained. To validate this screening result, we rescued the plasmid from 40 salt tolerant transformants, and re-introduced these plasmids to cnb 4 yeast cells. As shown Fig. 1, under normal medium conditions the growth of each transformant is almost similar to that of cnbs yeast cells harboring only the vector. However, a total of 34 colonies functionally suppressed the salt-sensitive phenotype of $c n b \Delta$ yeast cells (Fig. 1 ). Through sequencing analysis, these plasmids were determined to represent 9 genes and we named these suppressors as SRGs (ㅁalt-stress $\underline{\text { Related }}$ Genes, Table 1).

Expression of CaS genes in yeast gives rise to the increase of salt tolerance

To validate the usefulness of the yeast genetic system for screening plant salt tolerance genes, among SRG genes, we selected and studied the CaS gene, encoding extracellular

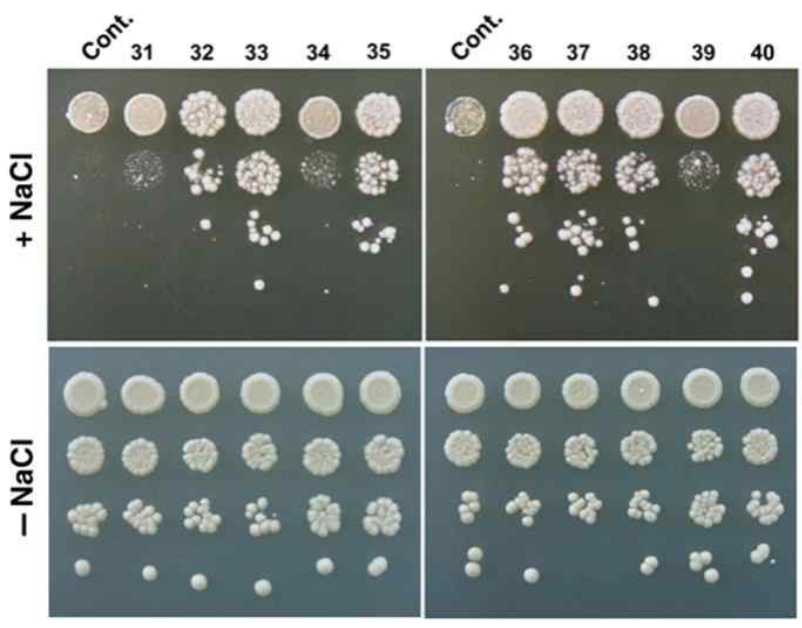

Fig. 1. Plant genes involved in salt stress tolerance were screened using a yeast genetic system. Plasmid DNAs which were isolated from the yeast cells suppressed salt sensitivity of the $\Delta c n b$ mutant. $2 \mu \mathrm{L}$ of each cell was spotted on YPD medium with or without $1.1 \mathrm{M} \mathrm{NaCl}$, and the photograph was taken after 3 days at $30^{\circ} \mathrm{C}$.
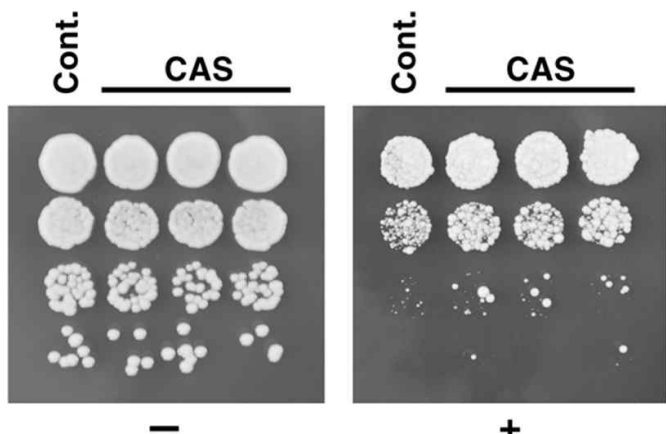

$\mathrm{NaCl}$

Fig. 2. Expression of CaS rescued the salt sensitive phenotype of $\Delta c n b$ mutant. The YP9 yeast strain was transformed with the plasmid containing CaS gene. Transformed cells were tested for salt tolerance on YPGal medium as described in Materials and Methods. The photograph was taken after incubation for 3 days at $30^{\circ} \mathrm{C}$.

Table 1. List of salt-stress related genes (SRGs)

\begin{tabular}{llcc}
\hline Name & Protein information & Accession No. & Screened colony No. \\
\hline SRG1 & Elongation factor 1a & At1g07930 & 4 \\
SRG2 & Transcription factor AtHB-12 & At3g61890 & 9 \\
SRG3 & Fructose 1,6-bisphospate aldolase & At3g52930 & 3 \\
SRG4 & SUMO1 & At4g26840 & 6 \\
SRG5 & APETELA3 & At3g54340 & 4 \\
SRG6 & Reticulon & At1g64090 & 2 \\
SRG7 & Extracelluar Ca ${ }^{2+}$ sensing receptor & At5g23060 & 3 \\
SRG8 & Ribosomal protein L19 & At2g43010 & 1 \\
SRG9 & Unknown protein & At1g64090 & 2 \\
\hline
\end{tabular}

cDNAs showing salt tolerance in yeast were rescued and sequenced with the dideoxy termination method, using a dye-terminator cycle sequencing kit. The sequencing reaction was analyzed using an automatic sequencer. 
$\mathrm{Ca}^{2+}$ sensing receptor (At5g23060). CaS consists of a single transmembrane domain, two $\mathrm{Ca}^{2+}$ binding motifs, and a rhodanese homology domain [9]. It was reported that CaS exhibits a low-affinity/high-capacity $\mathrm{Ca}^{2+}$ binding ability, and repression of $\mathrm{CaS}$ gene disrupts $\mathrm{Ca}^{2+}$ signaling in guard cells $[9,27]$. To further analyze whether the expression of CaS is able to confer tolerance to salt stress in yeast cells, we constructed full length $C a S$ gene in the episomal plasmid pYES2, placing it under the control of the GAL1 promoter, and tested galactose-dependent phenotype to $\mathrm{NaCl}$ stress. The transformants(Ed note: Spell checking of scientific terms is also carried out for all papers) harboring full length of CaS gene suppressed the NaCl-sensitive phenotype of cnbs yeast cells (Fig. 2).

CaS is specifically induced by $\mathrm{NaCl}$ stress in plants.

To identify the physiological role of CaS in plants, RNA expression levels were analyzed under $\mathrm{NaCl}$ stress conditions. Total RNA was isolated from Arabidopsis seedlings treated with $\mathrm{NaCl}$, and semi-quantitative RT-PCR was performed with CaS specific primers (Fig. 3). Transcript of KIN1 gene, which was used as positive control for $\mathrm{NaCl}$ treatment, was increased by high salinity treatment. The expression level of CaS gene was induced under high salinity conditions and a maximum transcript level was reached at $1 \mathrm{~h}$ of $\mathrm{NaCl}$ treatment. This result indicated that the biological role of $\mathrm{CaS}$ may be to mediate the $\mathrm{NaCl}$ stress response in plants.

CaS antisense transgenic plants showed sensitive phenotype to salt stress.

A CaS antisense transgenic plant was kindly provided by
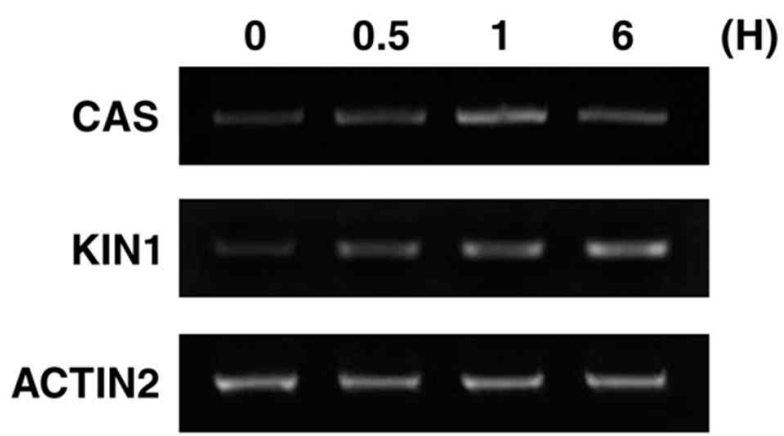

Fig. 3. Transcript level of CaS was increased by $\mathrm{NaCl}$ treatment. Total RNA was extracted from 2-week-old Arabidopsis seedlings treated with $100 \mathrm{mM} \mathrm{NaCl}$ for the indicated time, and semi-quantitative RT-PCR was performed using CaS-specific primers. KIN1 was used as a positive control, and ATCTIN2 was used as a quantitative control.

Prof. Zhen-Ming Pei of Duke University, USA. CaS transcript and protein was completely reduced in this CaS antisense transgenic plant [9]. To investigate the biological effect of CaS on salt stress tolerance, root elongation of CaS antisense transgenic plant was examined under salt stress conditions. No difference of root elongation was found between CaS antisense transgenic plants and wild-type plants under normal growth conditions. Root elongation of wild-type plants was not effected in MS medium containing $100 \mathrm{mM} \mathrm{NaCl}$ under our experiment conditions, however, root elongation of CaS antisense transgenic plants was reduced to $50 \%$ under the same conditions (100 mM NaCl treatment) (Fig. 4). Furthermore, root elongation of wild-type plants was severely impeded in MS medium containing $150 \mathrm{mM} \mathrm{NaCl}$, but wild-type plants were still survived. In the case of CaS

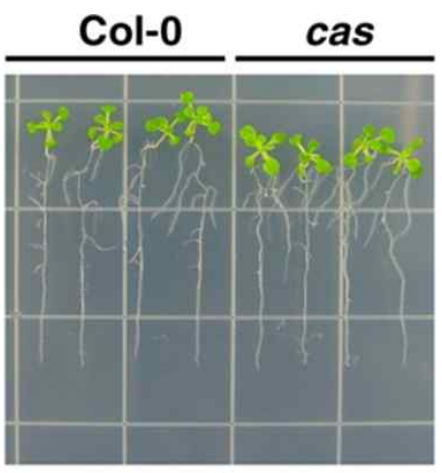

$\mathbf{0}$

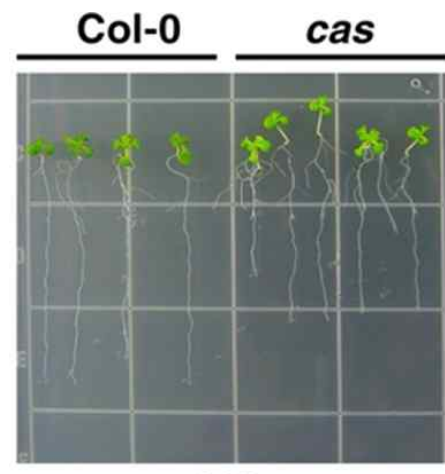

100

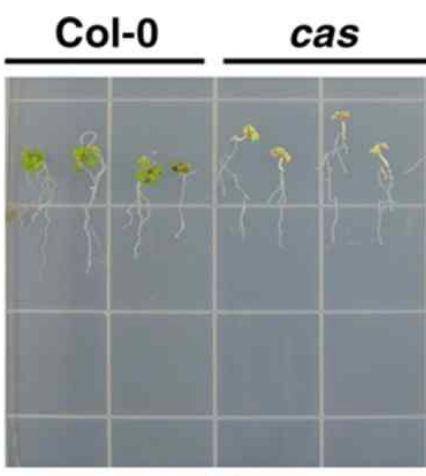

150
$\mathrm{NaCl}(\mathrm{mM})$

Fig. 4. CaS-antisense transgenic plants showed sensitive phenotype under high salinity conditions. 5-day-old seedlings of Col-0 and CaS-antisense transgenic plant were transferred to half-strength MS medium with or without $\mathrm{NaCl}$. The photograph was taken after an additional 7 days. 
antisense transgenic plants, root elongation was severely impeded and leaf color was altered to yellow under the experimental conditions (Fig. 4). This result suggests that the expression of $C a S$ is important for salt tolerance and $\mathrm{Ca}^{2+}$-mediated salt tolerance signaling is conserved between plant and yeast.

\section{Discussion}

Many stress-related genes in plants have been identified through diverse forward genetic approaches. However, the signal transductions and response mechanisms still remain to be understood. In this study, we used a yeast genetic system to identify plant genes showing salt tolerance, because genetic manipulation of yeast is a much simpl;et process than that of plants, and salt tolerance mechanisms, such as ion transport systems, are similar between plants and yeast [5]. Lippuner et al. used the salt-sensitive phenotype of yeast calcineurin mutants and identify two genes related to salt tolerance, STO and STZ [10]. Expression of Arabidopsis SR-like splicing proteins (AtRCY1) enhanced lithium and sodium tolerance in yeast and Arabidopsis [4]. Li-tolerant lipase 1 (AtLTL1) was screened for its functional expression in yeast [17]. AtLTL1 expression showed a weak tolerant phenotype to salt stress in yeast, but overexpression of AtLTL1 conferred salt tolerance in Arabidopsis [17]. We identified 9 kinds of salt tolerance genes, including $C a S$, using the yeast system (Table 1). Among these genes, SRG4 encodes small ubiquitin-like modifier 1 (AtSUMO1) which is important in posttranslational modifications of proteins. ABA- and stress-responsive genes, such as RD29 and AtPLC1, were up-regulated in AtSUMO1 overexpression transgenic plant [13]. Recently, it has been determined that SUMOylated proteins are accumulated in response to drought stress, and double mutants of SUMO protease genes, ots1 and ots2, showed salt sensitive phenotype in Arabidopsis [1, 2]. SRG1 encodes a homeobox-leucine zipper domain transcription factor 12, AtHB-12, which regulates sodium exclusion in yeast [25].

Perception of stress cues and relay of the signals to switch on adaptive responses are the key steps leading to plant stress tolerance. In plant cells, calcium $\left(\mathrm{Ca}^{2+}\right)$ serves as a second messenger and is a major point of signaling cross-talk during abiotic stress signaling [20]. Phytohormone ABA induces cytosolic free $\mathrm{Ca}^{2+}$ concentration oscillation in guard-cells, and oscillations in cytosolic $\mathrm{Ca}^{2+}$ led to stomatal closure $[7,26]$. High salinity stress also increases cytosolic free $\mathrm{Ca}^{2+}$ concentration [6]. Recently, it was reported that $\mathrm{NaCl}$-induced cytosolic free $\mathrm{Ca}^{2+}$ concentration was controlled through plasma membrane and intracellular $\mathrm{Ca}^{2+}$ permeable channels [28]. CaS gene was identified as an extracellular $\mathrm{Ca}^{2+}$ sensing receptor through a function screening assay in mammalian HEK293 cells [9]. CaS gene was mainly expressed in guard cells of leaf and CaS antisense transgenic plants had growth defects under low concentrations of $\mathrm{Ca}^{2+}$ [9]. CaS regulates concentrations of inositol 1,4,5-triphosphate $\left(\mathrm{IP}_{3}\right)$ and stomatal conductance in plant [27]. In here, we showed that the expression of CaS gene suppressed the salt-sensitive phenotype of cnbs yeast cells, and that CaS antisense transgenic plants were more sensitive than wild-type plants under high salinity conditions (Fig. 3 and 5). Even though yeast does not have guard cells, these results mean that cytosolic free $\mathrm{Ca}^{2+}$ concentration is important for salt tolerance in both yeast and plants.

\section{Acknowledgement}

This work was supported by a grant from the National Institute of Crop Science (PJ008685), Rural Development Administration, Republic of Korea.

\section{References}

1. Catala, R., Ouyang, J., Abreu, I. A., Hu, Y., Seo, H., Zhang, X. and Chua, N. H. 2007. The Arabidopsis E3 SUMO ligase SIZ1 regulates plant growth and drought responses. Plant Cell 19, 2952-2966.

2. Conti, L., Price, G., O'Donnell, E., Schwessinger, B., Dominy, P. and Sadanandom, A. 2008. Small ubiquitin-like modifier proteases OVERLY TOLERANT TO SALT1 and -2 regulate salt stress responses in Arabidopsis. Plant Cell 20, 2894-2908.

3. Espelund, M., Saeboe-Larssen, S., Hughes, D. W., Galau, G. A., Larsen, F. and Jakobsen, K. S. 1992. Late embryogenesis-abundant genes encoding proteins with different numbers of hydrophilic repeats are regulated differentially by abscisic acid and osmotic stress. Plant J 2, 241-252.

4. Forment, J., Naranjo, M. A., Roldan, M., Serrano, R. and Vicente, O. 2002. Expression of Arabidopsis SR-like splicing proteins confers salt tolerance to yeast and transgenic plants. Plant J 30, 511-519.

5. Forsburg, S. L. 2001. The art and design of genetic screens: yeast. Nat Rev Genet 2, 659-668.

6. Gao, D., Knight, M. R., Trewavas, A. J., Sattelmacher, B. and Plieth, C. 2004. Self-reporting Arabidopsis expressing pH and $\left[\mathrm{Ca}^{2+}\right]$ indicators unveil ion dynamics in the cytoplasm and in the apoplast under abiotic stress. Plant Physiol 134, 
898-908

7. Geiger, D., Scherzer, S., Mumm, P., Marten, I., Ache, P., Matschi, S., Liese, A., Wellmann, C., Al-Rasheid, K. A., Grill, E., Romeis, T. and Hedrich, R. 2010. Guard cell anion channel SLAC1 is regulated by CDPK protein kinases with distinct Ca2+ affinities. Proc Natl Acad Sci USA 107, 8023-8028.

8. Godoy, J. A., Pardo, J. M. and Pintor-Toro, J. A. 1990. A tomato cDNA inducible by salt stress and abscisic acid: nucleotide sequence and expression pattern. Plant Mol Biol 15, 695-705.

9. Han, S., Tang, R., Anderson, L. K., Woerner, T. E. and Pei, Z. M. 2003. A cell surface receptor mediates extracellular $\mathrm{Ca}(2+)$ sensing in guard cells. Nature 425, 196-200.

10. Lippuner, V., Cyert, M. S. and Gasser, C. S. 1996. Two classes of plant cDNA clones differentially complement yeast calcineurin mutants and increase salt tolerance of wild-type yeast. J Biol Chem 271, 12859-12866.

11. Liu, Q., Kasuga, M., Sakuma, Y., Abe, H., Miura, S., Yamaguchi-Shinozaki, K. and Shinozaki, K. 1998. Two transcription factors, DREB1 and DREB2, with an EREBP/AP2 DNA binding domain separate two cellular signal transduction pathways in drought- and lowtemperature-responsive gene expression, respectively, in Arabidopsis. Plant Cell 10, 1391-1406.

12. Liu, Y., Chakrabortee, S., Li, R., Zheng, Y. and Tunnacliffe, A. 2011. Both plant and animal LEA proteins act as kinetic stabilisers of polyglutamine-dependent protein aggregation. FEBS Lett 585, 630-634.

13. Lois, L. M., Lima, C. D. and Chua, N. H. 2003. Small ubiquitin-like modifier modulates abscisic acid signaling in Arabidopsis. Plant Cell 15, 1347-1359.

14. Mendoza, I., Quintero, F. J., Bressan, R. A., Hasegawa, P. M. and Pardo, J. M. 1996. Activated calcineurin confers high tolerance to ion stress and alters the budding pattern and cell morphology of yeast cells. J Biol Chem 271, 23061-23067.

15. Munns, R. and Tester, M. 2008. Mechanisms of salinity tolerance. Annu Rev Plant Biol 59, 651-681.

16. Nagaoka, S. and Takano, T. 2003. Salt tolerance-related protein STO binds to a Myb transcription factor homologue and confers salt tolerance in Arabidopsis. J Exp Bot 54, 2231-2237.

17. Naranjo, M. A., Forment, J., Roldan, M., Serrano, R. and Vicente, O. 2006. Overexpression of Arabidopsis thaliana LTL1, a salt-induced gene encoding a GDSL-motif lipase, increases salt tolerance in yeast and transgenic plants. Plant Cell Environ 29, 1890-1900.

18. Pouchkina-Stantcheva, N. N., McGee, B. M., Boschetti, C., Tolleter, D., Chakrabortee, S., Popova, A. V., Meersman, F., Macherel, D., Hincha, D. K. and Tunnacliffe, A. 2007. Functional divergence of former alleles in an ancient asexual invertebrate. Science 318, 268-271.

19. Raghavendra, A. S., Gonugunta, V. K., Christmann, A. and Grill, E. 2010. ABA perception and signalling. Trends Plant Sci 15, 395-401.

20. Reddy, A. S., Ali, G. S., Celesnik, H. and Day, I. S. 2011. Coping with stresses: roles of calcium- and calcium/calmodulin-regulated gene expression. Plant Cell 23, 2010-2032.
21. Sakamoto, H., Maruyama, K., Sakuma, Y., Meshi, T., Iwabuchi, M., Shinozaki, K. and Yamaguchi-Shinozaki, K. 2004. Arabidopsis Cys2/His2-type zinc-finger proteins function as transcription repressors under drought, cold, and high-salinity stress conditions. Plant Physiol 136, 2734-2746.

22. Seki, M., Narusaka, M., Ishida, J., Nanjo, T., Fujita, M., Oono, Y., Kamiya, A., Nakajima, M., Enju, A., Sakurai, T., Satou, M., Akiyama, K., Taji, T., Yamaguchi-Shinozaki, K., Carninci, P., Kawai, J., Hayashizaki, Y. and Shinozaki, K. 2002. Monitoring the expression profiles of 7000 Arabidopsis genes under drought, cold and high-salinity stresses using a full-length cDNA microarray. Plant J 31, 279-292.

23. Serrano, R. and Rodriguez-Navarro, A. 2001. Ion homeostasis during salt stress in plants. Curr Opin Cell Biol 13, 399-404.

24. Shi, H., Quintero, F. J., Pardo, J. M. and Zhu, J. K. 2002. The putative plasma membrane $\mathrm{Na}(+) / \mathrm{H}(+)$ antiporter SOS1 controls long-distance $\mathrm{Na}(+)$ transport in plants. Plant Cell 14, 465-477.

25. Shin, D., Koo, Y. D., Lee, J., Lee, H. J., Baek, D., Lee, S., Cheon, C. I., Kwak, S. S., Lee, S. Y. and Yun, D. J. 2004. Athb-12, a homeobox-leucine zipper domain protein from Arabidopsis thaliana, increases salt tolerance in yeast by regulating sodium exclusion. Biochem Biophys Res Commun 323, 534-540.

26. Staxen, I., Pical, C., Montgomery, L. T., Gray, J. E., Hetherington, A. M. and McAinsh, M. R. 1999. Abscisic acid induces oscillations in guard-cell cytosolic free calcium that involve phosphoinositide-specific phospholipase C. Proc Natl Acad Sci USA 96, 1779-1784.

27. Tang, R. H., Han, S., Zheng, H., Cook, C. W., Choi, C. S., Woerner, T. E., Jackson, R. B. and Pei, Z. M. 2007. Coupling diurnal cytosolic Ca2+ oscillations to the CAS-IP3 pathway in Arabidopsis. Science 315, 1423-1426.

28. Tracy, F. E., Gilliham, M., Dodd, A. N., Webb, A. A. and Tester, M. 2008. NaCl-induced changes in cytosolic free $\mathrm{Ca} 2+$ in Arabidopsis thaliana are heterogeneous and modified by external ionic composition. Plant Cell Environ 31, 1063-1073.

29. Wu, S. J., Ding, L. and Zhu, J. K. 1996. SOS1, a genetic locus essential for salt tolerance and potassium acquisition. Plant Cell 8, 617-627.

30. Yamaguchi-Shinozaki, K. and Shinozaki, K. 1993. Characterization of the expression of a desiccation-responsive rd29 gene of Arabidopsis thaliana and analysis of its promoter in transgenic plants. Mol Gen Genet 236, 331-340.

31. Yamaguchi-Shinozaki, K. and Shinozaki, K. 1994. A novel cis-acting element in an Arabidopsis gene is involved in responsiveness to drought, low-temperature, or high-salt stress. Plant Cell 6, 251-264.

32. Yokoi, S., Quintero, F. J., Cubero, B., Ruiz, M. T., Bressan, R. A., Hasegawa, P. M. and Pardo, J. M. 2002. Differential expression and function of Arabidopsis thaliana NHX $\mathrm{Na}+/ \mathrm{H}+$ antiporters in the salt stress response. Plant $J 30$, 529-539. 
33. Zhou, J., Wang, X., Jiao, Y., Qin, Y., Liu, X., He, K., Chen, C., Ma, L., Wang, J., Xiong, L., Zhang, Q., Fan, L. and Deng, X. W. 2007. Global genome expression analysis of rice in response to drought and high-salinity stresses in shoot, flag leaf, and panicle. Plant Mol Biol 63, 591-608.

초록 : 애기장대의 염해 저항성 관련 유전자의 기능적 선별

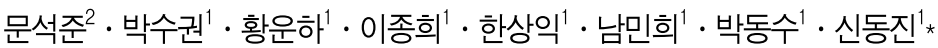

(농촌진흥청 ${ }^{1}$ 국립식량과학원 기능성작물부 신소재개발과, ${ }^{2}$ 국립농업과학원 생물자원부 분자육종과)

작물의 생산성 증가를 위해 염해 저항성 메커니즘을 이해하는 것이 중요하다. 식물의 염해 저항성에 관련된 유전자를 확보하기 위한 여러 가지의 선별방법이 개발되었다. 본 논문에서는 애기장대의 cDNA 라이브리를 염해 감수성 효모인 $\mathrm{cnb}$ 돌연변이체에 삽입하여 염해 감수성 표현형을 회복하는 콜로니를 선발하였다. 이 선별방법을 통하여 34종의 $\mathrm{cnb}$ 돌연변이체의 염해 감수성을 회복하는 콜로니를 선별하였으며, 염기서열분석을 통하여 $\mathrm{CaS}$ 와 AtSUMO1, AtHB-12 등 9종의 유전자임을 확인하였다. 이들 유전자 중 CaS의 발현이 염해 저항성을 증가시키는 것과 염해 처리에 의해 $\mathrm{CaS}$ 의 유전자의 발현이 증가되는 것을 확인하였다. $\mathrm{CaS}$ 발현억제 형질전환체는 $100 \mathrm{mM}$ 염처리에 의하여 뿌리생장이 저해되었다. 또한 $150 \mathrm{mM}$ 염처리에 의하여 $\mathrm{CaS}$ 발현억제 형질전환체의 잎에서 백 화현상을 나타내었다. 이러한 결과를 통하여 $\mathrm{CaS}$ 유전자가 효모와 식물에서 염해 저항성에 중요한 유전자임을 증명하였다. 